La Revista Panamericana de Salud Pública/Pan American Journal of Public Health se complace en publicar cartas de los lectores dirigidas a estimular el diálogo sobre los diversos aspectos de la salud pública en las Américas, así como a esclarecer, discutir o comentar de manera constructiva las ideas expuestas en la revista. Las cartas deben estar firmadas por el autor y especificar su afiliación profesional y dirección postal. Cuando se trate de comentarios sobre un artículo que requieran contestación del autor, se procurará conseguir esa respuesta con el fin de publicar ambas cartas. La Redacción se reserva el derecho de editar las cartas recibidas y resumirlas para mayor claridad.

The Revista Panamericana de Salud Pública/Pan American Journal of Public Health publishes letters from readers for the purpose of stimulating dialogue on various aspects of public health in the Americas and of constructively clarifying, discussing, and critiquing the ideas expressed throughout its pages. Letters should be signed by the author and include his or her professional affiliation and mailing address. If a commentary on a given article requires a reply from the author, an effort will be made to obtain the reply and to publish both letters. The editorial team reserves the right to edit all letters received and to condense them so as to improve their clarity.

\section{TOBACCO USE AMONG CUBAN MIGRANTS AT GUANTANAMO BAY, CUBA}

To the Editors:

We wish to call attention to a public health problem related to the U.S. military's policy on the availability of tobacco among Cuban migrants at Guantanamo Bay, Cuba.

As is well known, political challenges and economic hardship in Cuba contributed to a major population exodus in 1994. After taking to the water, often in unseaworthy boats, approximately 29000 to 35000 Cubans were intercepted in international waters by the U.S. Coast Guard and taken to Guantanamo Bay Naval Base (GTMO), Cuba. While the migrants were in detention camps waiting to be processed-a wait which usually lasted many months-the U.S. military distributed 20 cigarettes daily to each migrant over 18 years of age, regardless of the migrant's smoking status.

Tobacco use has been reported to be a major public health concern in Cuba. Although cigarettes were previously rationed in that country in order to increase tobacco export products, in the early 1980s Cuba ranked among the top five countries in the world in per capita smoking prevalence (1-3). In the mid-1980s, smoking-related diseases accounted for $30 \%$ of all deaths in Cuba (4). Couceyro (as cited in Matorrales-2) reported that $57 \%$ of Cuban men and $42 \%$ of Cuban women used tobacco. PadronGarcía reported a smoking prevalence of $43 \%$ among pregnant Cuban women (5), while Pletsch found the prevalence of smoking to be $22.6 \%$ among Cuban-American women of childbearing age (6). A Havana-based survey among firstthrough third-year nursing students found that $39.6 \%$ used tobacco (2).

Given the tremendous adverse effects of tobacco use on public health, and a surplus and hoarding of cigarettes in the GTMO camps (personal observation), a survey was conducted among the GTMO migrants to provide a baseline for initiating smoking prevention and cessation programs. The objectives of the study were to determine the prevalence of smoking in the Cuban migrant population, the age at smoking initiation, and the effect of a cigarette surplus in the camps on the initiation of the smoking habit.

In May 1995, a tent-to-tent smoking health risk survey was conducted in a section of one of the Cuban migrant camps occupied by 1600 men and 300 women. The overall Cuban migrant population at GTMO at the time was listed as 18037 men and 
2711 women distributed among 12 camps, three of which housed males only. The age distribution of the total migrant population was given as $4 \%$ between 4 months and 17 years, 56\% between 18 and 30 years, and the remaining $40 \%$ between 31 and 75 years. At the time of the survey, most of the migrants had lived in the camps for one year (7).

With the help of one Cuban translator/assistant, the survey was conducted over a two-week period. The questionnaire used for the survey contained closed-ended questions regarding demographic information and tobacco use history. The 26-item questionnaire was written in Spanish and had been pre-tested on 35 migrants who lived in another camp. The questionnaires were distributed about 11:00 a.m., by which time approximately 70\% of the migrants were in their tents in order to escape the hot sun, to play cards and dice games, and to socialize. Questionnaires and informed consent forms were distributed to occupants of two tents at a time; the number of people per tent averaged 14 . The assistant waited at each tent until the questionnaires were completed and returned. A total of 566 questionnaires (response rate $=95 \%$ ) were collected, representing 30\% of the target camp's population.

Among the 566 individuals who participated in the survey, $20 \%$ (111) were women and $80 \%$ (455) were men. Survey participants' ages ranged from 15 to 65 years. The overall female-to-male camp population ratio was 1:6.6, similar to the $1: 5$ ratio of the survey participants.

Forty-nine percent $(279 / 566)$ of the migrants used tobacco on a daily basis. The crude prevalence of smoking was $38 \%(42 / 111)$ for women and $52 \%$ $(237 / 454)$ for men. The highest prevalence of smoking was observed among persons aged 30 to 49 years for both women and men $(46 \%$ and $61 \%$, respectively), and the lowest among persons 15 to 19 (30\% for females and $28 \%$ for males). Among smokers, the median number of cigarettes smoked per day was 20 for males, 30 for women between the ages of 30 and 39 years, and 20 for women of other ages. Ninety-two percent $(256 / 279)$ of the smokers reported having a "sufficient" supply of cigarettes, while the remaining $8 \%(23 / 279)$ wanted more cigarettes.

Despite the abundance and general availability of cigarettes in the camps and the stressful living conditions, only $7 \%$ (21) of previously nonsmoking migrants had started smoking while in the camps: 6 women aged 22 to 43 years and 15 men aged 22 to 50 years. None of the previous nonsmokers reported smoking prior to arrival in GTMO. Nine, however, responded that at least one parent was a current smoker. The daily cigarette consumption of this group of new smokers ranged from 2 to 60 , with a median of 20 cigarettes. All of the new smokers cited stress as a factor contributing to their initiation of tobacco use.

Among all smokers, 57\% (158/279) began smoking by the age of 15 years. The mean age of first smoking increased with present age, with current teenagers initiating smoking at an average age of 15.4 years, 20-29-year-olds at 16.9 years, $30-39$-year-olds at 16.3 years, $40-49$-year-olds at 18.3 years, and 50-65-year-olds at 18.7 years. Gender-specific analysis showed that $25 \%$ of the male and female smokers had used tobacco by the ages of 14 and 13 years, respectively, while $75 \%$ had smoked by the time they reached 18 and 20 years of age, respectively.

The overall relative risk of respiratory problems (self-reported asthma, dyspnea, and bronchitis) associated with smoking was 1.7 (95\% confidence interval $(\mathrm{CI})=1.0$ to 2.8$)$, an increase attributable primarily to an increased risk among males (relative risk for males $=2.0(95 \% \mathrm{CI}=1.2$ to 3.6)). The prevalence of self-reported, chronic respiratory illness was $18.9 \%$ among smokers and $13.9 \%$ among nonsmokers. These prevalences seem high. It may be that this information was subject to overreporting because the definitions of asthma, chronic bronchitis, and shortness of breath were not included in the questionnaire. For example, a simple cough may have been reported as "bronchitis." Bang et al. reported age- and gender-specific chronic bronchitis prevalences of between $1.5 \%$ and $3.5 \%$ among Cuban-Americans (8).

The cigarette brands distributed in the GTMO camps were Pony (filter kings), made by the Star Tobacco Corp., Petersburg, Virginia (these cigarettes are U.S. tax-exempt for use outside the United States of America), and Class 'A' Quality Cigarettes (king size, filter lights), made by the Gary Tobacco Company, U.S.A./Permit No. TP-42NC. Packages for both brands exhibit a Surgeon General's warning in English. The Pony warning reads "Cigarette smoke contains carbon monoxide," while the warning on Class 'A' Quality Cigarettes packs reads "Quitting smoking now greatly reduces serious risks to your health." Essentially none of the migrants, however, could read either warning because of a language barrier.

The sampling plan utilized in the present study (a one-time, cross-sectional survey in one area of one of the camps) may have resulted in a sample that was somewhat unrepresentative of all migrants with respect to their smoking habits. Nevertheless, the overall smoking prevalence among Cuban men and women at Guantanamo Bay is similar to published data from Cuba, with a higher percentage of males than females who smoke $(2,5)$. 
According to the present survey, smoking habits are formed early in life, perhaps explaining why so few migrants $(7 \%)$ initiated tobacco use while incarcerated, despite the abundance of cigarettes and the stressful living conditions. However, even if only $7 \%$ of the total initially nonsmoking migrant population started smoking while incarcerated, an estimated 1100 to 1300 migrants became tobacco users among the 29000 to 35000 migrants taken to GTMO. Further, the military was under no obligation to provide cigarettes and, instead, could have limited the availability of cigarettes in the camps. Many migrants mentioned that they had increased their tobacco use while in the camps, a question that, regrettably, was not included in the survey questionnaire.

Because approximately $90 \%-95 \%$ of the 36000 Guantanamo Bay migrants immigrated to the United States, where cigarettes are readily available and affordable, the question of how the promotion of tobacco use at Guantanamo Bay affected their overall smoking habits is of particular relevance. If the prevalence of smoking continues at the level found in the present study, the future personal health care costs associated with smoking-related illness among Cuban-Americans will be substantial. The rationale for providing an abundance of free cigarettes in camps is not known. It seems imperative, however, that U.S. military leaders who are involved in migrant operations bear in mind the health consequences of their decisions regarding tobacco. In addition, the cost of operating migrant camps might be reduced substantially by limiting free daily cigarette distribution, which (at fifty cents per pack) is estimated to have cost over US\$ 5 million for the peak year at GTMO.

Heinke P. Bonnlander ${ }^{1}$ American Refugee Committee Rwandan Program BP 2680

Kigali, Rwanda

Annette MacKay Rossignol Department of Public Health Oregon State University Waldo Hall 322 Corvallis, OR 97331-6406, USA E-mail: rossigna@ccmail.orst.edu

\footnotetext{
1 At the time of the study, this author was employed at GTMO, Cuba, by the World Relief Corporation, which gave its permission for the study to be conducted.
}

\section{References}

1. Centers for Disease Control, US Public Health Service. Recent trends in tobacco consumption-Canada and other countries. Morbid Mortal Wkly Rep 1984;32:320-323.

2. Matorrales FE. Nursing and the smoking habit. Rev Cubana Enferm 1990;6:165-174.

3. Guttmacher S. The prevention of health risk in Cuba. Int J Health Serv 1987;17:179-189.

4. Masironi R, Rothwell K. Tendances et effets du tabagisme dans le monde. World Health Stat Q 1988;41:228-241.

5. Padron-García DM, Sánchez-Peres BB. Tobacco use and pregnancy. Rev Cubana Enferm 1990;6:62-68.

6. Pletsch PK. Prevalence of cigarette smoking in Hispanic women of childbearing age. Nurs Res 1991;40:103-106.

7. GTMO Joint Task Force. Migrant Operations Daily Update, Cuban Demographics. Wednesday, 3 May 1995.

8. Bang KM, Gergen PJ, Carroll M. Prevalence of chronic bronchitis among U.S. Hispanics from the Hispanic health and nutrition examination survey 1982-84. Am J Public Health 1990;80: 1495-1497.

\section{SERVICIOS PÚBLICOS DE SALUD: ¿UNA RESPUESTA A LA DEMANDA O A LA NECESIDAD?}

Señores:

En las postrimerías del siglo $\mathrm{XX}$, cuando solo faltan 3 años para llegar al 2000, estamos presenciando un movimiento social y una corriente económica que favorecen el individualismo, la autodeterminación y la soberanía del consumidor, y permiten rechazar los modelos preestablecidos. El mercado se ha legitimado como el mecanismo más eficiente para distribuir los recursos disponibles y la libertad de selección del consumidor parece tener preeminencia sobre los intereses de la colectividad. Ante esas profundas transformaciones sociales, el sector de la salud es presionado para que satisfaga las demandas individuales de usuarios más que las necesidades de salud de grupos poblacionales más amplios. ¿Deben, entonces, los servicios públicos de salud satisfacer al cliente o comprometerse con la colectividad y el mejoramiento objetivo de los indicadores de salud? Estas alternativas no necesariamente van de la mano y muchas veces se contraponen.

En el centro de esta polémica se debate si es o no conveniente que el financiamiento y la provisión de servicios de salud se abandonen al libre juego de la oferta y la demanda. Esta parecería ser la tendencia natural en escenarios donde se observa una creciente liberalización de la economía. Sin embargo, la 
provisión de servicios de salud debe ser objeto de un análisis distinto al de la producción y distribución de otros bienes y servicios. El mercado de servicios de salud presenta fallas que justifican la intervención del Estado en su provisión. En primer lugar, ni los productos que se ofrecen son comparables ni se garantizan los resultados. Hay un intermediario en la relación comercial -el médico- que introduce distorsiones en ese mercado. Además, la asimetría de información entre proveedor y consumidor es mucho más marcada que en otros mercados. Por otra parte, la provisión de ciertas intervenciones sanitarias ofrece a la sociedad externalidades positivas que no son objeto de comercialización. Considérese, por ejemplo, que los beneficios que obtienen los vecinos de un niño inmunizado no son objeto de transacción. Todo esto determina la imposibilidad de fijar precios de manera estable en el mercado de bienes y servicios de salud y justifica la participación del Estado como agente financiero y regulador.

Debido especialmente al desequilibrio de información entre proveedor y consumidor, las demandas de prestaciones de servicios de salud de los usuarios están bajo la influencia del complejo médico-industrial, en el que predomina la atención de salud curativa basada en tecnologías avanzadas. Por lo tanto, no es de extrañar que las necesidades sentidas por la población se orienten a la construcción de hospitales y a la dotación de medicamentos y tecnologías de última hora. Los servicios preventivos no son demandables en la misma medida porque los beneficios se observan solo en el largo plazo, el beneficiario particular no está claramente identificado y porque la promoción de la salud no es, necesariamente, un interés universalmente compartido por la práctica médica hegemónica. De esta forma los usuarios, desinformados o informados tendenciosamente, exigen atenciones curativas basadas en tecnologías avanzadas. Entre ellas, incluso, la atención al público y el servicio de alojamiento hospitalario parecen tener más importancia que los resultados concretos de las intervenciones.

La mayoría de los usuarios de los servicios de salud no suelen tener la capacidad para tomar decisiones clínicas y ceden esa responsabilidad a los médicos, que actúan como agentes en su nombre. Sin embargo, en las decisiones que toma el profesional de salud existe un conflicto de interés: su deseo de obtener mayores ingresos riñe con la intención del paciente de recuperarse al menor costo posible. ¿Deben, entonces, los responsables de la salud pública de un país liberar un mercado que cuenta con una demanda sumamente desorientada o asumir la responsabilidad de regular la provisión de servicios y mejorar los indicadores de salud por medio de las intervenciones más efectivas por el costo?
El objetivo de los servicios de salud no es producir satisfacción al momento de su consumo sino mejorar el estado de salud de los usuarios. En consecuencia, no tiene sentido prestar servicios de salud inefectivos, por más que estos sean exigidos.

Por cuanto los bienes y servicios de salud no son adecuadamente distribuidos por el mercado, cobra especial relevancia que su planificación sea conducida desde el aparato estatal. El Estado es responsable de diseñar y proponer la oferta de servicios que entregarán los distintos proveedores a la población. En el ámbito público, ello implica el diseño de paquetes básicos que norman la provisión de los servicios públicos y regulan la de los privados. Esos paquetes básicos, aunque hayan sido sometidos en ocasiones a una consulta popular - como en el estado de Oregón, Estados Unidos de América- están fuertemente influidos por el criterio de los técnicos que elaboran la propuesta.

Sin embargo, en los países donde no se ha utilizado rigurosamente ninguna metodología para establecer la efectividad de las intervenciones clinicoasistenciales, como es el caso de la mayoría de los países de América Latina, estas guardan una relación más estrecha con las demandas espontáneas de los usuarios y los intereses del complejo industrial que con criterios de beneficio social.

Por las razones expuestas, la primera tarea para aprovechar al máximo los recursos destinados a la prestación de servicios de salud parece ser la de afinar los criterios que guían a los planificadores de la salud al asignar los recursos financieros. Ya sea mediante procedimientos trabajosos desde el punto de vista metodológico, como el cálculo de los años de vida ajustados por discapacidad (AVAD) propuesto por el Banco Mundial, o con metodologías más acordes a los sistemas de información de los países en desarrollo, es necesario que los planificadores del sistema de prestación de servicios de salud establezcan las intervenciones que logren el mayor impacto poblacional en función de los recursos disponibles. Al mismo tiempo, se requiere educar a la población en el beneficio social de la oferta de servicios diseñada por técnicos, de manera que la demanda de la población en servicios de salud se aproxime, paulatinamente, a la que tenga el mayor impacto social en años de vida ganados y ajustados por discapacidad o cualquier otro indicador que dé cuenta de la efectividad de las intervenciones.

El Estado debe promover la orientación de los servicios de salud hacia aquellas intervenciones que ofrecen el mayor impacto social, objetivamente traducido en mejoras de los indicadores de salud. Una oferta de servicios eficiente, socialmente aceptable y acorde al acomodo social en curso solo puede ser producto de la más alta precisión técnica y de una 
amplia consulta social que contraponga los argumentos científicos que fundamentan la propuesta técnica con las preferencias y valores sociales que justifican su modificación. El producto final de este proceso participativo será la selección concertada de un conjunto de intervenciones, probablemente aun lejos de la mayor eficiencia técnica, pero socialmente aceptadas y validadas.

Además de promover ese proceso de consulta, la labor fundamental del Estado es desarrollar un amplio programa de información pública que permita a los usuarios tomar decisiones mejor sustentadas, tanto en el ámbito público como en el privado. Solo cuando la información esté mejor equilibrada entre proveedores y consumidores podrán aproximarse las preferencias de los usuarios a los criterios técnicos que redundan en el mayor beneficio social.

Edgar Barillas

Consultor en Salud Internacional GSD Consultores Asociados

36 ave. $1-39$ zona 7

Guatemala 01007

Correo electrónico: gsd@guate.net

\section{EVALUATION OF A NOVEL DRINKING WATER TREATMENT AND STORAGE INTERVENTION IN NICARAGUA}

\section{To the Editors:}

The cholera epidemic in Latin America has spotlighted inadequate water quality and sanitation in the Region. The long-term solution to this problem would be for every community to have piped, disinfected water as well as sewage treatment facilities, but sufficient resources to provide such services do not exist. An alternative strategy for improving water quality shows promise. This strategy has three parts: (1) point-of-use water treatment with sodium hypochlorite solution produced locally with appropriate technology; (2) safe water storage in special, narrow-mouthed water storage vessels; and (3) community education (1). A field trial in El Alto, Bolivia, showed that a community of Aymara Indians using this intervention was able to produce drinking water that met WHO guidelines for micro- biologic water quality (2). In a second trial in Montero, Bolivia, a group of households using the intervention had $44 \%$ fewer episodes of diarrhea than did neighboring con-trol households (3). To evaluate this strategy in Central America, we tested a similar intervention in Asedades, Nicaragua, a poor, rural community of approximately 1100 persons, between January and April 1996.

A convenience sample of 100 households was selected to receive the intervention, which consisted of an 80-liter plastic, lidded storage vessel equipped with a spigot for extracting water (referred to as the "special vessel"); sodium hypochlorite solution produced in the neighboring town of Boaco, Nicaragua, using a Dip Cell hypochlorite generator (Magneto-Chemie, Ltd., Holland); and community education. Between 8 and 11 January 1996, the community received education about diarrheal disease prevention and proper use of the intervention materials. From 11 to 17 January 1996, we conducted a baseline survey of demographic characteristics and water-handling practices of each participating household. In midJanuary, the community formed a "water committee" composed of eight persons responsible for reinforcing the educational messages and helping resolve problems in the use of the intervention materials. Then the vessels and hypochlorite solution were distributed. Participants were instructed to put $10 \mathrm{~mL}$ of disinfectant in the vessels each time they filled them. From 15 to 19 April 1996, we conducted follow-up surveys in all homes that received the intervention, checking chlorine residuals in water in the special vessels using the DPD colorimetric method (Hach Co., Loveland, Colorado).

The median age of the survey respondents was 40 years (range 14 to 80 ), and $83 \%$ were female. Among the 100 persons surveyed, 45 had no formal education, 53 had from 1 to 6 years of schooling, and 2 could not provide that information. Overall, 642 persons lived in the 100 households surveyed, for a median household size of 6 (range 1 to 13). Household water sources included covered wells with rope-pumps $(61 \%)$, a river $(26 \%)$, a spring $(10 \%)$, or a combination of sources $(3 \%)$. Of the 96 respondents who stored drinking water in their homes, 68 (71\%) used 20-liter wide-mouthed plastic buckets, $24(25 \%)$ used wide-mouthed earthenware jars, and $4(4 \%)$ used both. For water treatment, $68 \%$ of respondents said they used chlorine when it was available, $5 \%$ said they put chlorine in their wells, and $26 \%$ said they used nothing. At the time of the baseline survey, chlorine was not available in the community.

In the follow-up survey, all 100 respondents said that their household was using the special ves- 
sel. Ninety-nine percent of the vessels were observed to have water in them, $98 \%$ had lids in place, $100 \%$ had a functioning spigot, and $5 \%$ were observed to be dirty. Of the 98 water samples obtained, 51 (52\%) had detectable free chlorine residuals, with a median residual of $0.4 \mathrm{mg} / \mathrm{L}$ (range 0.2 to 3.5$)$. Fifty-four (55\%) of the water samples had detectable total chlorine, with a median residual of $0.4 \mathrm{mg} / \mathrm{L}$ (range 0.2 to 3.5). Of 100 study participants, 85 could state the correct amount of hypochlorite disinfectant to add to the full water vessel.

This study demonstrated that the majority of the population of Asedades complied with the use of this novel water intervention. Although neither microbiologic water quality nor diarrhea rates were measured in this study, results from the Bolivian studies $(2,3)$ suggest that an improvement in both outcomes would have been likely in the Asedades population. Interventions of this type are inexpensive, simple, easy to implement, and have been shown to be acceptable to several different populations. They offer a promising alternative approach to improving water quality in the developing world and deserve further study.
Jonathan T. Macy

Department of International Health The Rollins School of Public Health

of Emory University 1518 Clifton Road N.E. Atlanta, GA 30322, USA

Robert E. Quick Foodborne and Diarrheal Diseases Branch Centers for Disease Control and Prevention

\section{References}

1. Mintz ED, Reiff FM, Tauxe RV. Safe water treatment and storage in the home: a practical new strategy to prevent waterborne disease. JAMA 1995;273:948-953.

2. Quick RE, Venczel LV, Gonzales O, et al. Narrow-mouthed water storage vessels and in situ chlorination in a Bolivian community: a simple method to improve drinking water quality. Am J Trop Med Hyg 1996;54:511-516.

3. Quick RE, Venczel LV, Mintz ED, et al. Diarrhea prevention in Bolivia through safe water storage vessels and locally produced mixed oxidant disinfectant. In: Program and Abstracts of the 35th Interscience Conference on Antimicrobial Agents and Chemotherapy [17-20 September 1995; San Francisco, CA]. Washington, DC: American Society for Microbiology; 1995. (Abstract K142). 